On the growth of foreign affiliates:

Multinational plant networks, joint ventures, and flexibility

René Belderbos and Jianglei Zou

DEPARTMENT OF MANAGERIAL ECONOMICS, STRATEGY AND INNOVATION (MSI) 


\title{
On the Growth of Foreign Affiliates: \\ Multinational Plant Networks, Joint ventures, and Flexibility
}

\author{
Suggested running head: On the Growth of Foreign Affiliates
}

René Belderbos

Katholieke Universiteit Leuven and Technische Universiteit Eindhoven

\author{
Jianglei Zou
}

Katholieke Universiteit Leuven

Corresponding author:

René Belderbos

Katholieke Universiteit Leuven

Faculty of Economics and Applied Economics

Department of Managerial Economics and Strategy, and Innovation

Naamsestraat 69

B-3000 Leuven

Belgium

Phone + 3216326912

Fax + 3216326732

Email: Rene.belderbos@econ.kuleuven.be 


\title{
On the Growth of Foreign Affiliates:
}

\section{Multinational Plant Networks, Joint ventures, and Flexibility}

\begin{abstract}
We take a flexibility perspective to analyze employment growth in a large sample of Japanese manufacturing affiliates in nine Asian countries during the years leading up and into the Asian financial crisis (1995-1999). We find that joint ventures are less flexible than wholly owned affiliates in responding to changing environmental conditions in the focal country and underperform in high growth environments. Multinational enterprises use the flexibility created by their multinational plant network to adjust affiliate employment in response to labor cost changes in other countries in which they operate plants. However, no evidence was found that the presence of joint ventures in multinational plant networks reduces this network flexibility. Our findings suggest that more research is needed on the heterogeneous responses of multinational enterprises and their affiliates to changing economic environments.
\end{abstract}

Keywords: Affiliate growth, joint ventures, plant networks, flexibility 


\section{INTRODUCTION}

A growing body of literature has examined why, how, and where multinational enterprises (MNEs) invest abroad through acquisitions, the establishment of greenfield affiliates, or joint ventures. A large number of studies have examined the firm-level determinants of the decision to become a MNE (e.g. Belderbos and Sleuwaegen, 1996; Kogut and Chang, 1991; 1996), the choice of entry mode abroad (Delios and Beamish, 1999b; Hennart, 1991; Barkema and Vermeulen, 1998), and the location choice for new affiliates (Head et al., 1995; Shaver and Flyer, 2000; Chung and Alcacer, 2001; Belderbos and Carree, 2002). Other studies have examined the impact of multinational expansion and geographic scope on overall firm performance (Delios and Beamish, 1999a; Hitt et al, 1997; Tallman and Li, 1996). Surprisingly little attention has however been devoted to the subsequent growth of foreign affiliates of MNEs once they are established. This is an important omission in the international business literature, since growth in existing operations can be an important contributor to MNEs' sales and employment growth complementing new affiliate investments ${ }^{1}$. A limited number of studies examine foreign affiliate growth from an industrial organization perspective, in which growth is regarded as the result of differential efficiency levels and adaptive learning (Blonigen and Tomlin, 2001), or from a resource-based perspective, focusing on the impact of managerial resource constraints on (consecutive) growth (Tan, 2003; Tan and Mahoney, 2005).

In this paper we contribute an analysis of employment growth in a large sample of Japanese manufacturing affiliates in nine Asian countries during the years leading up and into the Asian financial crisis (1995-1999). We take a flexibility perspective on the growth of foreign affiliates, in which affiliates' growth is regarded as heterogeneous responses of MNEs to changing economic conditions in the focal country and other countries in which the firms are active. Differences in affiliate employment growth not only result from differences in efficiency or managerial resources, but are also determined by differences in the operational flexibility with which firms can respond to environmental changes. This flexibility of affiliates is hypothesized to depend on two characteristics that are specific to foreign affiliates of MNEs: the affiliate's position in the investing firm's multinational plant network and the affiliate's entry mode. A flexibility perspective on foreign affiliate growth is opportune given the increasing research attention paid in the international business literature to multinational flexibility (Buckley and Casson, 1998; Rangan, 1998). This partly reflects

\footnotetext{
${ }^{1}$ For instance, Belderbos and Zou (2006), using comparable data on Japanese affiliates in Asia as in this paper, report that employment in existing affiliates grew by almost 120,000 employees during 1995-1999 while employment created in new affiliates amounted to about 140,000 employees.
} 
the trend that MNEs increasingly manage their overseas affiliates as a network of interdependent facilities (Kogut, 1985), and configure and coordinate the production in these affiliates in a systematic and integrated manner (Belderbos and Sleuwaegen, 2005; Ernst, 1997).

Our study is the first to systematically analyse growth of foreign manufacturing affiliates of MNEs in multiple countries, which allow us to examine the impact on growth of multinational plant networks and regional environmental changes in addition to focal country factors. The investigation period, a period that includes the first years of the Asian financial crisis that led to divergent cost and demand developments in countries in the Asian region, provides an interesting environment to analyse intra-regional employment adjustments in affiliates of MNEs. Our analysis corrects for sample selection bias arising from the fact that we only observe growth in affiliates that did not exit during the period.

\section{LITERATURE AND HYPOTHESES}

\section{Previous Literature}

The process of firm growth was first systematically studied in the industrial organization literature on entry, exit, and post-entry performance of firms. Theoretically, Jovanovic (1982) modeled the expansion of firm as an adaptive learning process. He argued that firms learn about their efficiency only gradually and, under uncertainty, tend to enter with a relative small size. Successful firms subsequently increase their size as their efficiency reveals itself, and unsuccessful firms exit at an early age when they are still small. His model predicts that, at a given point in time, larger firms and older firms are more likely to have been growing successfully in the past and hence have a higher probability of survival, compared with their smaller and younger counterparts. At the same time, surviving smaller and younger firms will grow faster. Empirical studies in this tradition have found evidence that firm growth indeed is negatively related to firm size (Mansfield, 1962; Evans, 1987a; Kumar, 1985; Hall, 1987; Dunne et al, 1989), and to firm age (Evans, 1987b; Dunne et al, 1989; Dunne and Hughes, 1994). ${ }^{2}$ Later studies have examined the impact of several other industry and firm characteristics on plant growth and found positive impacts of the introduction of advanced technology (Doms et al.,1995), fixed investments in intangible assets (Dixit, 1989; Hopenhayn, 1992), and reduced risk factors (Rosenberg, 2004).

\footnotetext{
${ }^{2}$ These results imply a significant departure from Gibrat's law, which suggests that firm growth is a stochastic process that is independent of firm traits (Sutton, 1997).
} 
Another stream of research has examined firm growth from a resource-based perspective. According to Penrose (1959), the rate at which a firm can grow at a period of time is mainly constrained by the finite capacity the firm's managerial resources. In order to grow, firms incur substantial adjustment cost in altering their resource base to meet market requirements (Treadway, 1970; Hamermesh and Pfann, 1994). Due to these adjustment costs, there are limits to the growth rate at which a firm can increase its resource base at any point in time. This "Penrose effect" in the growth of firms has been examined in several empirical studies (e.g. Gander, 1991; Thompson, 1994; Shane, 1996; Orser et al., 2000). These studies have concluded that firms' managerial capacity needs to increase significantly as firms expand (Gander, 1991), and that it is difficult for firms to achieve two consecutive years of strong growth (Orser et al, 2000).

In contrast with the large number of studies on firm growth in a domestic setting, the specific growth patterns of foreign affiliates of MNEs have only been sparsely studied. There has been significant interest in the international business literature in the heterogeneous roles and responsibilities of foreign subsidiaries and autonomous changes in such roles, but most of these empirical studies have been of a cross section nature rather than employing longitudinal analysis (e.g. Rugman and Verbeke, 2001). The literature on the performance of foreign affiliates has focused its attention almost exclusively on the determinants of survival or divestment of foreign affiliates (Hennart et al, 1998; Li, 1995; Mata and Portugal, 2002; Mata and Portugal, 2000; Shaver et al, 1997; Belderbos and Zou, 2005). ${ }^{3}$

Only a few studies have explicitly examined the growth of foreign affiliates of MNEs, and these studies have usually been confined to a single host country setting. Blonigen and Tomlin (2001) examined employment growth in Japanese manufacturing plants in US during 1987-1990, and confirmed that smaller and younger plants grow faster, consistent with the adaptive learning theory developed by Jovanovic (1982). Tan (2003) and Tan and Mahoney (2005) examined the relevance of the resource-based perspective in a foreign affiliate setting. Tan (2003), analyzing the growth rate of Japanese affiliates in US, confirmed that affiliate growth was positively affected by the managerial resources assigned to the affiliates. Tan and Mahoney (2005) extended this analysis and found that rapid growth in one time period had a negative impact on growth in the subsequent time period, in

\footnotetext{
${ }^{3}$ These divestment studies have uncovered an extensive set of factors that can affect the survival of foreign affiliates, such as the size and experience of the affiliate (Benito, 1997; Shaver et al, 1997; Zaheer and Mosakowski, 1997), the market focus of the affiliate (Chen and $\mathrm{Wu}, 1996$; Pan and Chi, 1999), the extent of diversification of entry (Li, 1995), parent experience gained through previous international expansion (Li, 1995; Shaver et al, 1997; Delios and Beamish, 2001), human capital and technology advantages (Mata and Portugal, 2000; Delios and Beamish, 2001; Belderbos, 2003) and affiliate capabilities related to embeddedness in the host country (Song, 2002).
} 
support of the dynamic adjustment costs argument. Two other studies of foreign affiliate growth have focused on the differences in growth patterns depending on the entry mode of affiliates. Williams (2003) studied employment growth of foreign manufacturing affiliates in the UK and found that greenfield affiliates and higher value added affiliates tended to grow faster. Mata and Portugal (2004) found that the post-entry behaviour of foreign owned firms is different from that of their domestic counterparts. Acquired affiliates were found to have significantly lower post-entry growth rates than greenfield entries, which they attributed to the larger scale and smaller learning potential of acquired plants. ${ }^{4}$

\section{Flexibility and Affiliate Growth}

As has been pointed out by Buckley and Casson (1998), flexibility is the "hallmark of recent modelling of the multinational enterprises". It can be generally defined as "the ability to reallocate resources quickly and smoothly in response to changes". The strategic management literature has long recognized the important strategic implications of organizational flexibility for firms (Aaker and Mascarenhas, 1984), and identified different types of flexibility that firm should maintain, depending on the managerial capabilities required, the firm resources involved, and the impact on firms' strategic objectives and routines. Two types of flexibility that can be distinguished are strategic flexibility and operational flexibility (De Toni and Tonchia, 2005). Strategic flexibility is a radical type of flexibility that allows changes in the nature of firm activities and has far-reaching consequences for strategy and performance (Volberda, 1996; Aaker and Mascarenhas, 1984). It can be regarded as a firm's capability to identify major changes in its external environment, both domestic and international, commit resources to new courses of action in responses to these changes, and to recognize and act promptly when it is time to halt or reverse such resource commitments (Shimizu and Hitt, 2004). Operational flexibility, on the other hand, refers to the routine activities of a firm. It relates to the volume and mix of activities undertaken by a firm and does not involve fundamental changes of course of a firm's strategy (Volberda, 1996). Operational flexibility allows firm to respond quickly to more common environmental changes, leading to temporary adjustments in firms' manufacturing, distribution, or financial operations.

It has long been recognized that, due to their control over manufacturing facilities in multiple countries, MNEs have greater degrees of flexibility than uni-national firms (Dunning and Rugman,

\footnotetext{
${ }^{4}$ A related study by Song (2002) did not examine growth of individual affiliates per se, but studied the 'upgrading' or 'downgrading' of manufacturing activities at the firm level in three Asian countries by Japanese MNEs. He found that upgrading or downgrading is dependent on the level of embeddedness of the MNEs in the host country, reflected in characteristics such as local procurement and the appointment of local managers.
} 
1985). The international business strategy literature has suggested at least two major vehicles through which MNEs can achieve flexibility on the markets in which they are present: the establishment of multinational plant networks in multiple countries and the use of international joint ventures (IJVs) to enter foreign markets. The flexibility implications of multinational plant networks have been discussed both at the strategic and the operational level. In strategic terms, the multinational plant network of a MNE can be seen as a network of country platforms (Kogut and Kulatilaka, 1994b). Arguments derived from real options theory suggest that under uncertainty concerning environmental developments, such country platforms can represent significant option value, if they allow firms to develop valuable intangible assets specific to each country (Kogut and Chang, 1996). Country platforms can provide firms with the strategic flexibility to invest swiftly and profitably in a country by leveraging the intangible assets and accumulated country expertise if uncertainty resolves and environmental conditions turn out to be favourable. ${ }^{5}$ The multinational plant network also provides flexibility at the operational level. This is the flexibility of adjusting capacity loadings of plants in different countries in response to environmental changes such as exchange rate movements or differences in factor costs (Rangan, 1998; Lessard, 1986; Ghosal, 1987; Miller and Reuer, 1998; Kogut and Kulatilaka, 1994a; Kulatilaka and Trigeorgis, 1994; Trigeorgis, 1996). In terms of real options theory, firms benefit from the possibility to exercise the switching options provided by the network. The value creation of such operational flexibility for MNEs has been formally modelled by researchers in economics, finance and management (Huchzermeier and Cohen, 1996; Kogut and Kulatilaka, 1994a; Mello and Parson, 1995), and has also been investigated empirically (Allen and Pantzalis, 1996; Tang and Tikoo, 1999; Goerzen and Beamish, 2003).

Traditional research on IJVs has applied a transaction cost approach, regarding IJVs as a superior mode of entry when the markets for the assets contributed by both partners fail (Hennart, 1991). MNEs trade off a reduction in control over the foreign ventures against access to complementary host country resources embedded in the local partner firm (e.g Stopford and Wells, 1972; Anderson and Gatignon, 1982; Hill et al, 1990; Kim and Hwang, 1992). Entry through joint ventures also allows spreading risk over multiple capital providers (Kogut and Singh, 1988), overcoming the liability of foreigness, and obtaining host country specific knowledge (Inkpen and Beamish, 1997; Zaheer and Mosakowski, 1997; Contractor and Lorange, 1988). The latter advantages are emphasized in the real options approach to IJVs that stresses strategic flexibility (Kogut,1991; Reuer and Leiblein, 2000). In this view, a joint venture is a favourable entry mode in

\footnotetext{
${ }^{5}$ In terms of real options theory firms 'call' the growth option of the platform investment (Kogut, 1983).
} 
the presence of environmental uncertainty. It combines an option for waiting, as the joint venture reduces the MNE's resource commitments, and an option for future growth in the host country, since the joint ventures can serve as a platform for developing host country-specific intangible assets reducing the liability of foreignness. Kogut (1991) argues that the exercise of the growth option may occur through acquisition of the local partner's shares, or new investments in greenfield plants that can also involve withdrawal from the joint venture. While the real options approach emphasizes the strategic flexibility provided by IJVs, it does not provide predictions on their operational flexibility. ${ }^{6}$

The extant literature has not yet examined the consequences of MNE flexibility for affiliate growth. In what follows, we examine these consequences and derive hypotheses on the impact of multinational plant networks and IJVs on affiliate growth. As the focus of our study is on growth processes in existing affiliates, it is the operational flexibility of affiliates and across the network that is relevant, rather than strategic flexibility. In this operational flexibility perspective on affiliate growth, growth is dependent on the degree to which the MNE can flexibly adjust operations in affiliates in response to environmental changes in the focal country as well as in other countries in which the firm has established its affiliate network.

\section{Hypotheses}

Our review of the literature suggests that previous studies have paid little attention to the growth of foreign manufacturing affiliates. Moreover, the role of environmental changes in foreign countries has not been examined in detail due to the limitation of analysis to single-country settings. Below we develop hypotheses on the impact of environmental changes on affiliate growth and the heterogeneous responses of affiliate to these environmental changes due to differences in operational flexibility.

Theories of the MNE have long established the importance of host country characteristics in the internationalization decisions of MNEs (Dunning, 1993; Caves, 1996, Buckley and Casson, 1979; Vernon, 1979). Buckley and Casson (1979) stress that market size, as related to the presence of scale economies, is crucial in foreign investment decisions. The product cycle theory of Vernon (1979)

\footnotetext{
${ }^{6}$ The value of joint ventures as growth options has been studied in the context of downward risk implications (Reuer and Leiblein, 2000), and MNEs' entry mode choice in response to uncertainty in real exchange rate movements (Kouvelis et al, 2001) and market uncertainty (Chi and McGuire, 1996). Recent studies have further explored the application of the real options approach to IJVs and suggest that type of uncertainty (exogenous vs. endogenous to the venture) is an important moderator of the impact of the option value of joint ventures on MNE's entry mode decisions (Li and Rugman, 2005; Cuypers and Martin, 2006).
} 
emphasizes the international dynamics of demand growth and labour costs as determining changing investment patterns. Empirical studies have confirmed that MNEs are more likely to locate plants in large (regional) markets (e.g. Head et al, 1995; Mayer and Muchielli, 1999) and regions with lower labour cost (Belderbos and Carree, 2002; Mayer and Muchielli, 1999; Wheeler and Mody, 1992). As market demand and labour costs are the environmental changes that are most influential in attracting investments, changes in market demand and labour costs are also likely to lead MNEs to extend or reduce operations of existing affiliates. ${ }^{7}$ In particular in industries with a global character in terms of production locations (such as the electronics industry examined in our empirical application), two major motivations for investments are to produce goods for growing domestic markets and to reduce manufacturing costs by benefiting from lower labour costs. Demand growth in the host country allows the expansion of production without necessarily inviting stronger rivalry with competitors (e.g. Benito, 1997). Labour cost growth reduces profitability of expansions and may illicit the more intensive use of labour-saving capital, reducing employment growth. ${ }^{8}$ This leads to the following hypothesis:

Hypothesis 1: Foreign affiliates grow faster, the greater host country demand growth and the smaller host country labour cost growth.

The extent to which affiliates show faster or slower growth in response to environmental changes depends on the operational flexibility to adjust to these changes. Here we expect IJVs to show adjustment patterns that are different from wholly owned affiliates. The transaction cost approach to IJVs emphasizes a reduced control over the venture, which points to a potentially reduced operational flexibility compared with wholly owned plants. A number of arguments in the IJV literature support this. IJV partners tend to differ in goals, values, and company routines (Pangarkar and Klein, 2004), and these differences are likely to lead to management conflict and higher complexity in control and ownership structures (Hennart et al, 1998; Fey and Beamish, 2000; Yan and Zeng, 1999). Differences in the national origin of the partners can lead to communication problems (Barkema et Vermeulen, 1997), and shared decision making process in joint ventures make it difficult for venture partners to reach agreements

\footnotetext{
${ }^{7}$ A third motivation, access to local technological developments, is not a major motivation in the less developed countries in South East Asia.

${ }^{8}$ A number of related empirical studies on affiliate divestment have generally confirmed that factors attracting foreign investments also increase the probability of survival. Benito (1997), Shaver (1995), and Mata and Portugal (2002) found positive impacts of host country demand growth, while Song (2002) and Belderbos and Zou (2005) found that labour cost increase reduces survival probabilities. Similar positive impacts of industry shipment growth and demand growth have been found in studies of domestic plant growth (Mata and Portugal, 1994).
} 
(Killing, 1982, 1983; Glaister, 1995; Hennart et al, 1998). ${ }^{9}$ The above factors are likely to make joint ventures inherently less able to respond swiftly to environmental changes, which hinders optimal adjustment to these changes by the MNE. As joint ventures are governed by incomplete contracts, there will be ambiguities in the way to respond to cost and demand changes, and such environmental changes may lead to divergent interests between the local firm and the foreign investor on the type of response. In case of positive environmental change, partners may have problems to agree on the extent of new capital investments (e.g. one partner may have difficulties financing expansion, perhaps requiring renegotiations of equity stakes). In case of negative developments in the local environment, local partners may be less willing to reduce production capacity and employment given their commitments to local unions and suppliers. Hence, joint ventures are likely to be characterized by a lower degree of operational flexibility to respond to relevant environmental changes. This leads to the following hypothesis.

\section{Hypothesis 2: The impact of host country environmental changes on affiliate growth is smaller for} joint ventures than for wholly owned affiliates.

The second moderator of operational flexibility is the position of affiliates in the MNEs' multinational network of manufacturing plants. Here the focus is not on flexibility with respect to changes in the focal country, but on flexibility with respect to adjustments to environmental changes in other countries in which the network is established (hereafter we refer to these countries as "network countries"). The real options perspective on multinational plant networks suggests that by operating a multinational plant network in multiple locations under uncertainty about future economic conditions, the MNE can benefit from the switching options created by the network. This option represents the flexibility of adjusting capacity loadings and employment in plants in different countries in response to environmental changes such as exchange rate movements or differences in labour and other factor costs (Rangan, 1998; Lessard, 1986; Miller and Reuer, 1998; Kogut and Kulatilaka, 1994a; Kulatilaka and Trigeorgis, 1994; Trigeorgis, 1996). MNEs aim to optimize production operations across countries this way in order to minimize production costs. ${ }^{10}$ Hence, growth of affiliates of MNEs that operate such a network of plants in multiple countries does not only respond to cost changes in the focal country, but also

\footnotetext{
${ }^{9}$ These management complexities related to joint ventures have been suggested as the determinant of the greater incidence of divestments among joint venture affiliate compared with wholly owned firms ( $\mathrm{Li}, 1995$; Yamawaki, 1997; Hennart et al, 1998; Kim and Delios, 2003).

${ }^{10}$ In well integrated international markets, divergent trends in market demand are less likely to be reflected in adjustment in affiliate growth across the network, as intra-firm export or imports allows the MNE to optimize the network in terms of cost minimization.
} 
to cost developments in other countries that the network covers. ${ }^{11}$ This impact of environmental change in other countries does not occur, or at much slower pace, for affiliates that are not part of a firm's multinational plant work. It follows that, while labour cost in the focal country is expected to have a negative impact on employment growth of affiliates, labour cost growth in network countries stimulates relocation of production to the focal country and positively impacts affiliate growth:

Hypothesis 3: Affiliates of MNEs operating a network of plants in multiple countries grow faster, the greater the labour costs increase in other countries in which the network is established.

The arguments concerning the lower operational flexibility of IJVs compared with wholly owned affiliates also suggest a moderating impact of entry mode on the adjustments to environmental changes in the network. The entry mode choice literature has pointed out that joint ventures are a less suitable choice for MNEs that adopt a global integrated plant network strategy (Hill et al., 1990). In order to manage their overseas manufacturing affiliates as an integrated multinational plant network and to be able to constantly adjust production in each node in the network optimally to the relative cost and market conditions in host countries, MNEs need to maintain a high degree of control over its affiliates, so that production and other strategic and operational activities in these affiliates can be fully coordinated. Potential management conflicts between the MNE and local joint venture partner(s), and incomplete control over decision-making processes, hamper such coordination if the network includes joint venture affiliates. Similarly, a real options perspective on IJVs would imply that, while IJVs create benefits in terms of strategic flexibility and host country growth options, they are not appropriate vehicles to create switching options in the multinational plant network. This suggests two moderating impacts of IJVs on network flexibility. First, a joint venture is less likely to respond flexibly to labour cost changes in network countries (just as it's response to focal country environmental change is expected to be weaker). Second, in case IJVs have a strong presence in the network of manufacturing affiliates of the MNE, the scope for network-wide adjustment of operations and cost minimization is reduced. This leads to the following related hypotheses:

\section{Hypothesis 4: The impact of labour cost increases in other countries on affiliate growth is smaller for} joint ventures than for wholly owned affiliates.

\footnotetext{
${ }^{11}$ It should be noted that owning a multinational plant network itself does not guarantee operational flexibility. In order to enjoy such flexibility, manufacturing facilities of the MNE in different countries need to be well integrated in terms of management and information flows (Rangan, 1998).
} 
Hypothesis 5: The impact of labour cost increases in other countries on affiliate growth is smaller, the greater the presence of joint ventures among affiliates in the network.

\section{DATA AND EMPIRICAL METHODS}

\section{Data}

Our dataset consists of 1041 manufacturing affiliates operational in early 1995 that were wholly or partially controlled by 412 Japanese firms in the broadly defined electronics industry in 9 Asian countries or regions, i.e. South Korea, Taiwan, China, Hong Kong, Singapore, Indonesia, Philippines, Malaysia, and Thailand. The data are compiled by the Research Institute of Electronic Industry as "Asia Shinsutsu Denshi Meika" (Survey of Japanese electronic firms in Asia, Denshi Keizai Kenkyuujo, 1996; 1999) in Tokyo in 1995 and early 1999. It is an authoritative source on Japanese foreign investments in Asia in the electronics industry with complete coverage of investments by both large firms, small and medium sized firms, and specialized suppliers to the electronics industry (glass, plastic, metals, chemical materials). The data give a reliable picture of investments by both leading electronics firms and smaller vertical business group-related or unrelated suppliers along the value chain of the electronics industry. The database contains information on the affiliates' paid-in capital, number of employees, equity stake held by Japanese investors, direction of sales, and products manufactured, and it also contains parent firm information on sales, number of employees, paid-in capital, and recent developments in the firms' overseas operations. Among the 1041 affiliates, 1035 affiliates had complete data and could be included in the analysis. 95 out of these 1035 affiliate were found to have been divested before early 1999 while the other 940 affiliates remained in operation ${ }^{12}$. It is the employment growth of these remaining affiliates that we study, while controlling for the divestment cases. The country distribution of the 1035 affiliates and descriptive statistics of employment growth and divestment are presented in Table 1.

\section{Insert table 1}

\footnotetext{
12 The confirmation of divestment was given by the parent information provided for each Japanese firm on such decisions in the 1999 edition of the survey, combined with information from other publications by the Research Institute of Electronics Industry on developments in Japanese electronics firms (such as quarterly compilations of press releases), other sources on Japanese affiliates abroad (Toyo Keizai, 1999), and coverage in Japanese newspapers drawn from the Nikkei web news service.
} 


\section{Model specification}

Our dependent variable is the average annual growth rate of affiliate's employment from 1995 to early 1999. Since only the employment growth of those affiliates that survive until early 1999 can be calculated, the analysis would suffer from selection bias if we estimate on the sample of surviving affiliates. Since growth and survival are not independent of each other, we have to correct for the fact that we selected the sample of surviving firms and do not analyse the potential worst performers (divested affiliates). In order to correct for this sample selection bias, we adopt the two-step estimation method proposed by Heckman $(1976,1979)$. In the first step, a Probit survival equation is estimated of the probability that an affiliate survived between 1995 and 1999. From this equation we derive the Inverse Mill's ratio representing the non-survival hazard of an affiliate. This ratio is subsequently included as a right hand side variable in the growth equation. The Heckman two-step estimation method to correct for sample selection bias can be represented formally by the following equation:

$$
\begin{aligned}
& \text { Survival }_{i}=\operatorname{Prob}\left(\mathrm{X}_{1 \mathrm{i}} \beta_{1}\right)+\mu_{1 i} \\
& \text { Growth }_{i}=\mathrm{X}_{2 \mathrm{i}} \beta_{2}+\sigma_{12} \lambda_{i}+\mu_{2 i}
\end{aligned}
$$

Equation 1 is the Probit estimation of affiliate survival. The dependent variable is a binary variable that takes value 1 if a 1995 affiliate survives until early 1999, with vector $\mathrm{X}_{1 \mathrm{i}}$ a set of country, affiliate, and parent firm regressors as determinants. We relegate the discussion of explanatory variables in the survival equation and the estimation results of this equation to Appendix I. Equation 2 is the ordinary least squares estimation of affiliate employment growth, with $\mathrm{X}_{2 \mathrm{i}}$ the vector of explanatory variables, among which a subset is also included in $\mathrm{X}_{1 \mathrm{i}}$. The regressor $\lambda_{i}$, the inverse mill's ratio, controls for the probability of an affiliate being selected into the growth equation, and its coefficient $\sigma_{12}$ is equal to the covariance of the disturbances of the survival and growth equations $\mu_{1 i}$ and $\mu_{2 i}{ }^{13}$

\footnotetext{
${ }^{13}$ The inverse mill's ratio $\lambda$ is represented as $\phi\left(\mathrm{X}_{1 \mathrm{i}} \beta_{1}\right) / \Phi\left(\mathrm{X}_{1 \mathrm{i}} \beta_{1}\right)$, with $\phi$ and $\Phi$ are, respectively, density and distribution function for a standard normal variable. See Greene (1997).
} 


\section{Operational Measures}

Hypothesis 1 concerns the responses of affiliates to labour cost growth and demand growth in the host country. In the setting of Japanese electronics firms in Asia, demand growth in a country is the percentage growth in the value of the electronics demand in the country between 1995 and 1998. Labour cost growth is measured as the annual increase in the yearly dollar wage in the country's electronics industry during this period. Hypothesis 1 predicts a positive impact for the former and a negative for the latter. Hypothesis 2 is tested by an interaction effect between the dummy variable joint venture (which takes value 1 if parent firm holds less than 95\% stake in the affiliate) ${ }^{14}$ and the variables measuring focal country demand growth (with a negative moderating impact expected) and labour cost growth (with a positive moderating impact expected), respectively. In order to test hypothesis 3, we introduce the variable network labour cost growth, the average labour cost growth in those Asian countries in which the multinational parent firm had manufacturing operations in 1995, except for the focal country. Hence our empirical test examines regional (Asian) network integration rather than world-wide network effects. ${ }^{15}$ Hypothesis 3 predicts a positive impact on employment growth. Hypothesis 4 predicts a negative sign for the interaction effect of joint venture with network labour cost growth. Hypothesis 5 is tested by interacting network labour cost growth with the variable share of joint ventures in network. Share of joint ventures in network measures the ratio of the number of joint ventures to the total number of affiliates in the network (with the exception of the focal country). Hypothesis 5 predicts a negative sign, as the variable is expected to moderate the positive impact of labour cost increases across the network.

\section{Control variables}

We include an extensive set of control variables that may affect the employment growth of foreign affiliates. These represent factors at the parent, affiliate, and host country level.

\section{Parent level characteristics}

\footnotetext{
${ }^{14}$ Distinguishing between the impacts of minority owned versus majority owned joint ventures showed no significant differences between these two types of joint ventures in moderating the effect of environmental changes.

${ }^{15}$ Earlier research on actual relocations of manufacturing activities by Japanese firms in Asia based on newspaper report and specialized publications did not produce a single case of relocation outside of Asia (Belderbos and Zou, 2006).
} 
We include Parent size, which is measured by the logarithm of parent firm sales in 1995. The impact of parent size on employment growth can be in both directions. Larger firms may be more patient with poorly performing affiliates and report lower growth more regularly for their affiliates. On the other hand, larger firms are likely to possess more (financial) resources to expand production more rapidly.

We include Parent patent intensity (the number of US patent granted to the parent firm during 1993-1999 times 1000, divided by parent sales in 1995), as proxy for intangible assets and competitive advantages of parent firms based on advanced technology that are likely to enhance the performance of their affiliates (Delios and Beamish, 2001; Belderbos, 2003). At the same time, technology intensive firms may be more likely to realize growth through technology upgrading and investments in sophisticated machinery, which may lead them to exhibit smaller rates of employment growth.

Parent prior country experience (the number of affiliates established by the parent firm in the country prior to the establishment of the focal affiliate) will impact growth positively if MNEs reduce their "liability of foreigness" by learning from prior experience in the host country allowing them to increase the performance of their affiliates. Blonigen and Tomlin (2001), on the other hand, argue that foreign affiliates of firms with previous country experience grow less fast as the individual affiliates have less to learn about the host country.

\section{Affiliate level characteristics}

Consistent with the entry and exit theory of Jovanovic (1982), there is ample empirical evidence that firm growth is negatively related to firm size and firm age, and such relationships have been found to hold also for foreign affiliate (Blonigen and Tomlin, 2001). We include affiliate size (the logarithm of the number of employees of the affiliate in 1995) and affiliate age (the number of years the affiliate had been in operation until 1995) as controls variables. In order to accommodate the possible non-linear effect of affiliate age on growth, we also include the square term of affiliate age (affiliate age square).

Besides size and age, at the affiliate level we also want to control for a possible main effect of entry mode on employment growth. We include 2 entry mode dummies with wholly owned greenfield affiliates as reference group: joint venture (taking the value 1 if the affiliate is a joint venture in which the Japanese parent held less than 95\% stake, and acquired affiliate (dummy taking the value 1 if the affiliate was acquired by the Japanese parent). 
The resource based perspective on firm growth suggests inclusion of a proxy for managerial resources. We included the variable expatriate intensity as a proxy for the managerial resources assigned by the parent firm to the affiliate, which may facilitate growth. Expatriate intensity is the number of Japanese expatriates divided by the total number of employees in 1995.

\section{Country level characteristics}

The country level variables labor cost growth and demand growth (as defined above), cover the two major motivations for foreign affiliate establishment and growth, in particular in the Asian electronics industry. In addition, we include the variable FDI inflow (the average dollar value of annual inward direct investment flows to the country between 1995 to 1998) as a broad measure of attractiveness of the countries correlated with regulatory and other changes that are relevant to the host country investment environment.

Descriptions and summary statistics for the dependent variable, operational measures and control variables are given in Table 2. A correlation matrix is provided in Appendix II.

Insert table 2

\section{EMPIRICAL RESULTS}

The results from Heckman estimation of affiliate employment growth are reported in Table 3. The table reports the estimation results of seven models. Model 1 only includes the control variables. In model 2 the variables labor cost growth and demand growth are added (Hypothesis 1). Model 3 adds the interactions of these variables with joint ventures (Hypothesis

2). Model 4 tests for Hypothesis 3 (network demand growth) in absence of the joint venture interactions. Model 5 adds the interaction of network labor cost growth and joint venture (Hypothesis 4). Model 6 focuses on the interaction between network labor cost growth and the share of joint ventures in network (Hypothesis 5). Model 7 then tests all hypotheses simultaneously.

All models are highly significant as indicated by the Chi-square test statistic. The inverse mill's ratio $(\lambda)$ has the expected negative sign and is significant in all models. This suggests that 
survival and subsequent growth of foreign affiliates are indeed interrelated processes, and that selection bias in the affiliate growth equation requires using the two-step method. The consistent negative sign of $\lambda$ indicates that affiliates having a low probability of survival during the period exhibit lower employment growth, which is intuitive.

\section{Insert table 3}

In all 7 models, the focal country demand growth is positive and highly significant, while labor cost growth is negative and highly significant, lending strong support for Hypothesis 1 . In model 3 and model 7, the interaction of joint venture dummy with labor cost growth is positive, and that with demand growth is negative, and all these interactions are significant. These results strongly support Hypothesis 2: joint ventures are significantly less responsive to environmental changes in the focal country. In models 4-7, network labor cost growth is consistently positive and significant (at the 5 percent level in modesl 4-6, and at the 10 percent level in model 7), in support of Hypothesis 3. The interaction of network labor cost growth with joint venture, as well as the interaction with the share of joint ventures in network, has the expected negative sign throughout, but the coefficients are not significantly different from zero. Hence, we do not find evidence supporting a moderating effect of entry mode on the impact of network labor cost growth (Hypotheses 4 and 5).

The impact of the control variables is largely consistent with previous findings. Parent size is positive and highly significant, suggesting that larger firms either are more competitive or that they can rely on greater resources to expand employment in their affiliate. Parent patent intensity is positive, and parent prior country experience is negative, but neither of the variables is significant. Consistent with previous studies of firm growth and foreign affiliate growth, both affiliate size and affiliate age have a significantly negative impact on employment growth. The square term of affiliate age is positive and highly significant, suggesting that the marginal impact of extra years of age tapers off as affiliate age increases. ${ }^{16}$ The joint venture dummy has a negative sign throughout, and in models 2, 5 and 6 (when interactions between joint venture with country variables are excluded) the coefficient reaches significance at the 10 percent level. The acquired affiliate dummy is also negative, but does not reach significance. Expatriate intensity has a positive sign in all models except model 1, but it neither reaches statistical significance. The country variable FDI inflow is significant and

\footnotetext{
${ }^{16}$ Since the turning point (about 45 years) is out of the age range of the firms in our sample, the data do not support a employment increasing impact of age for any of the affiliates.
} 
positive in model 1 as expected. In the hypotheses testing models its coefficient switches sign but is no longer significantly different from zero.

\section{CONCLUSION AND DISCUSSION}

This paper analyzed employment growth in 940 Japanese electronics manufacturing affiliates in nine Asian countries during the years leading up and into the Asian financial crisis (1995-1999). We developed a flexibility perspective on the growth of foreign affiliates, in which affiliate growth is regarded as a heterogeneous response of the MNE to changing economic conditions in the focal country and other countries in which the firm is active. Differences in affiliate employment growth not only result from differences in efficiency or managerial resources, but are also determined by differences in the operational flexibility with which firms can respond to environmental changes. This flexibility of affiliates is hypothesized to depend on two characteristics that are specific to foreign affiliates of MNEs: the affiliate's position in the MNEs' multinational plant network and the affiliate's entry mode.

Using an econometric methodology that corrects for estimation bias resulting from the selection of a sample of surviving affiliates, we found evidence that the entry mode affects affiliates' capacity to adjust to environmental change in the host country. While host country labor cost growth generally has a strong negative impact on foreign affiliates' employment growth, this impact is significantly smaller for joint ventures than for wholly owned affiliates. Similarly, joint ventures show a significantly smaller positive response to host country demand growth compared with wholly owned ventures. This confirmed our hypothesis that joint ventures are characterized by a lower level of operational flexibility in adjusting to new market opportunities or cost changes, due to renegotiation costs, more cumbersome decision making processes, and diverging interests of foreign investor and local partner(s). The second moderator of MNE flexibility, the presence of a multinational plant network established in multiple countries, was also found to impact affiliate growth. Affiliates grow faster if labor costs increase in other countries in which the network of the MNE is established, indicating that MNEs shift activities across countries in response to international cost developments. This suggests that MNEs adopt a systematic approach to adjustments in manufacturing operations of plants across their multinational network in order to benefit from the operational flexibility that the network provides. The finding is in line with the real options perspective on the advantages of investments in multinational plant networks. In this view, operating a network of manufacturing plants in locations with uncertainty and potentially divergent 
macroeconomic developments creates switching options for the MNE, which are exercised through relocation of manufacturing activities in response to disparities in labor cost developments.

The empirical results did not support the hypothesis that the presence of joint ventures in multinational plant networks reduces operational flexibility across the network, and neither were joint ventures found to be less responsive to labor cost changes within the network. This contrasts with the notion that MNEs intending to pursue global integrated strategies prefer to operate wholly owned greenfield affiliates in which they have full management control, rather than joint ventures (Hill et al. 1990). On the other hand, this result appears in line with findings in Kim and Hwang (1992), who neither could confirm a systematic relationship between global strategies and entry modes. One possible reason for the insignificant findings may be that other factors than joint venture presence increase or mitigate network flexibility. Whether plants produce similar or very dissimilar products may for instance be important to facilitate operational adjustments across the network. Another factor impacting network flexibility is the degree of intra-firm trade and management integration across affiliates, which shape the interrelatedness of affiliates operations in the network, while they are not necessarily related to joint venture status. We lacked adequate data on all these influences to test alternative or more detailed hypotheses, or to control for these possible influences. The results raise interesting questions for further research and call for the construction of databases on affiliates across countries that includes information on intra-firm trade, labor skill makeup, and the integration of management.

The strong findings on the differential responses of joint ventures to focal country environmental change points at the distinction between strategic and operational flexibility. Joint ventures appear less flexible in adjusting to host country opportunities directly, and are inflexible in an operational sense. This contrasts with the real options approach to international joint ventures, which rather stresses the strategic flexibility they provide (Kogut, 1991; Reuer and Leiblein, 2000). In this view, joint ventures are chosen because they reduce resource commitments while providing value as a growth option: they can serve as platforms for developing host country-specific intangible assets allowing the firm to expand if growth opportunities materialize. These contrasting notions may be reconciled if we consider that the exercise of joint ventures' growth option does not necessarily involve expansion within the joint venture itself, but could take a more strategic response, involving acquisition of the venture, or divestment from the venture combined with the establishment of a new affiliate. In our study we restricted the analysis to growth in surviving affiliates of MNEs, abstracting from potential growth in manufacturing operations in the region through the establishment of new affiliates. A natural future extension of this analysis is to study growth in MNE operations at the country level, which would allows investigating growth responses to environmental changes taking into account jointly divestments, differential growth in existing affiliates, and employment growth in new affiliates. 
Our analysis has implications for the study of the performance of foreign affiliates and, more specifically, research on affiliate growth. Our study shows that it is essential to take MNEs' plant networks into account in studying affiliate performance. This corresponds to the view that firms increasingly adopt integrated global strategies, coordinating activities of their overseas affiliates and assigning different roles depending on their location, capabilities, and position in the global network of their parent firms (e.g. Birkinshaw and Morrison, 1995; Kim and Hwang, 1992). The literature on affiliate performance and growth has however largely focused on foreign owned affiliates in a single country, ignoring the interaction with the international strategy of the firms. Our results also show that affiliate growth is a consequence of responses of firms to changes in their domestic and international environment, rather than being a simple function of firm and affiliate characteristics. Hence, characteristics of firms and affiliates may not necessarily have a systematic direct impact on growth and performance, but instead lead to different dynamic responses to changes in economic environments. These divergent responses may either lead to lower or higher growth rates in the adjustment process. Future research in international business strategy could benefit from a focus on dynamic strategy changes in the context of environmental contingencies, for which longitudinal databases on affiliate operations across countries would have to be developed.

A limitation of our study is the restriction of the sample to affiliates in the (broadly defined) electronics sector in Asia in a specific, though interesting, period of change. This restriction reduces the scope for generalizations. The existence of extensive plant networks by MNEs in different countries in Asia, the importance of labor costs, and the 'footloose' nature of manufacturing plants are to an extent particular to assembly industries such as the electronics industry. It will be interesting to see if consistent findings can be found for foreign affiliates by MNEs in other industries, and for network flexibility at a global rather than regional level. 


\section{REFERENCES}

Aaker, D.A. and Mascarenhas, B. (1984) 'The Need for Strategic Flexibility', Journal of Business Strategy, 5(2): 74-82.

Allen, L. and Pantzalis, C. (1996) 'Valuation of the Operating Flexibility Of Multinational Operations', Journal Of International Business Studies, 27(4): 633-53.

Anderson, E. and Gatignon, H. (1986) 'Modes of Foreign Entry: A Transaction Cost analysis and Propositions', Journal of International Business Studies, 17(3):1-26.

Barkema, H. G. and Vermeulen, F. (1998) 'International Expansion through Start-Up or Acquisition: A Learning Perspective', Academy of Management Journal, 41(1):7-26.

Belderbos, R. (2003) 'Antidumping and Tariff Jumping Divestment', Review of World Economics, 139(1):131-160.

Belderbos, R. and Carree, M. (2002) 'The location of Japanese investment in China: Agglomeration effect, Keiretsu and firm heterogeneity', Journal of Japanese and International Economies, 16(2): 194-211.

Belderbos R, and Sleuwaegen, L. (2005) 'Competitive Drivers and International Plant Configuration Strategies: A Product Level Test’, Strategic Management Journal, 26(6): 577-593.

Belderbos, R. and Sleuwaegen, L. (1996) 'Japanese Firms and the Decision to Invest Abroad: Industrial Groups and Regional Core Networks', Review of Economics and Statistics, 78(2): 214-220.

Belderbos, R. and Zou, J.L. (2006) 'Foreign Investment, Divestment and Relocation by Japanese Electronics Firms in East Asia'. Asian Economic Journal, 20(1): 1-27.

Belderbos, R. and Zou, J.L. (2005) 'Divesture of foreign manufacturing affiliates: country platforms, multinational plant networks, and foreign investor agglomeration', Paper presented at 2005 annual meeting of Academy of International Business, Québec, July, 2005.

Benito, G.R.G. (1997) 'Divestment of Foreign Production Operations', Applied Economics, 29(10): $1365-1377$.

Birkinshaw, J.M. and Morrison, A.J. (1995) 'Configurations of Strategy and Structure in Subsidiaries of Multinational Corporations', Journal of International Business Studies, 26(4):729-753.

Blonigen, B.A., and Tomlin, K. (2001) 'Size and growth of Japanese plants in the United States', International Journal of Industrial Organization, 19(6):931-952.

Buckley, P.J and Casson, M. (1976) The Future of Multinational Enterprises. Holmes \& Meier, London..

Caves, R. E. (1996) Multinational Enterprise and Economic Analysis, 2nd edition. Cambridge, MA: MIT Press.

Chen,T.J. and Wu, G. (1996) 'Determinants of Divestment of FDI in Taiwan', Welwirtschaftliches Archiv, 136:172-184.

Chi, T. and McGuire, D. J. (1996) 'Collaborative Ventures and Value of Learning: Integrating the Transaction Cost and Strategic Option Perspectives on the Choice of Market Entry Modes', Journal of International Business Studies, 27(2): 285-307.

Chung, W. and Alcácer, J. (2002) 'Knowledge Seeking and Location Choice of Foreign Direct Investment in the United States', Management Science, 48 (12):1534-1554.

Contractor, F.J. and Lorange, P. (1988) 'Why should firms cooperate? The strategy and economics basis for cooperative ventures'. In F.J. Contractor \& P. Lorange (Eds.), Cooperative strategies in international business: 3-30. New York: Lexington Books.

Cuypers, I.R.P. and Martin, X. (2006) 'What Makes and What Does Not Make a Real Option? A Study of International Joint Ventures', Academy of Management Best Paper Proceedings. 
Delios, A., and Beamish, P. W. (2001) 'Survival and Profitability: the Roles of Experience and Intangible Assets in Foreign Subsidiary Performance', Academy of Management Journal, 44 (5):1028-1038.

Delios, A. and Beamish, P.W. (1999a) 'Ownership Strategy of Japanese Firms: Transactional, Institutional, and Experience Influences', Strategic Management Journal, 20(10):915-934.

Delios, A. and Beamish, P. W. (1999b) 'Geographic scope, product diversification and the corporate performance of Japanese firms', Strategic Management Journal, 20(8):711-728.

Denshi Keizai Kenkyuujo, (1999). Asia Shinshutsu Denshi Meika (Japanese electronics firms in Asia). Denshi Keizai Kenkyuujo.Tokyo.

Denshi Keizai Kenkyuujo, (1996). Asia Shinshutsu Denshi Meika (Japanese electronics firms in Asia). Denshi Keizai Kenkyuujo.Tokyo.

De Toni, A. and Tonchia, S. (2005) 'Definitions and Linkages between Operational and Strategic Flexibilities', Omega (The International Journal of Management Science), 33(6): 525-540.

Dixit, A. (1989) 'Entry and Exit Decisions under Uncertainty', Journal of Political Economy, 97(3): 620-638.

Doms, M., Dunne, T. and Roberts, M.J. (1995) 'The Role of Technology Use in the Survival and Growth of Manufacturing Plants', International Journal of Industrial Organization, 13(4):523542.

Dunne, P. and Hughes, A. (1994) 'Age, Size, Growth and Survival: UK Companies in the 1980s', The Journal of Industrial Economics, 42(2):115-140.

Dunne, T., Roberts, M. J. and Samuelson, L. (1989) 'The growth and failure of U.S. manufacturing plants', Quarterly Journal of Economics, 104(4): 671-698.

Dunning, J. (1993) Multinational Enterprises and the Global Economy. Addison-Wesley, New York.

Dunning, J., and Rugman, A.M. (1985) 'The Influence of Hymer's Dissertation on the Theory of Foreign Direct Investment', American Economic Review, 75 (2) : 228-232.

Ernst, D. (1997) 'From Partial to Systemic Globalization: International Production Networks in the Electronics Industry'. BRIE working papers, 1-114.

Evans, D.S. (1987a) 'Test of Alternative Theories of Growth', Journal of Political Economy, 95(4): 657-674.

Evans, D.S. (1987b) 'The Relationship Between Firm Growth, Size, and Age: Evidence for 100 Manufacturing Industries', Journal of Industrial Economics 35(4):567-581.

Fey, C.F. and Beamish, P.W. (2000) 'Joint Venture Conflict: The Case of Russian International Joint Ventures', International Business Review, 9(2):139-60.

Gander, J.P. (1991) 'Managerial Intensity, Firm Size and Growth'. Managerial and Decision Economics, 12(3): 261-266.

Ghoshal, S. (1987) 'Global strategy: an organizing framework', Strategic Management Journal, 8(5): 425-440.

Glaister, K. W. (1995) 'Dimensions of Control in UK International Joint Ventures', British Journal of Management, 6(2): 77-96.

Goerzen, A. and Beamish, P.W. (2003) 'Geographic Scope and Multinational Enterprise Performance', Strategic Management Journal, 24(13): 1289-1306.

Greene, W.H. (1997). Econometric Analysis, Englewood Cliffs, NJ, Prentice Hall.

Hall, B.H. (1987) 'The Relationship between Firm Size and Firm Growth in the US Manufacturing Sector', The Journal of Industrial Economics, 35(4): 583-606.

Hamermesh, D. and Pfann, G. (1994) 'Adjustment Costs in Factor Demand'. Journal of Economic Literature 34(3): 1264-1292.

Head, K., Ries, J. and Swenson, D. (1995) 'Agglomeration benefits and location choice: Evidence from Japanese manufacturing investments in the United States', Journal of international economics, 38(3/4): 223-247. 
Heckman, J.J. (1979) 'Sample Selection Bias as a Specification Error', Econometrica 47(1):153-161. Heckman, J.J. (1976) 'The Common Structure of Statistical Models of Truncation, Sample Selection, and Limited Dependent Variables and a Simple Estimator of Such Models', Annals of Economic and Social Measurement, 5(4): 475-492.

Hennart, J. F. (1991) 'The Transaction Costs Theory of Joint Ventures: An Empirical Study of Japanese Subsidiaries in the United States', Management Science, 37(4): 483-497.

Hennart, J. F., Kim, D. J. and Zeng, M. (1998) 'The Impact of Joint Venture Status on the Longevity of Japanese Stakes in U.S. Manufacturing', Organization Science, 9 (3):382-395.

Hill, C.W.L., Huang, P. and Kim, C. (1990) 'An Eclectic Theory of the Choice of International Entry Mode', Strategic Management Journal, 11(2):117-128.

Hitt, M. A., Hoskisson, R. E. and Kim, H. (1997) 'International diversification. Effects on innovation and firm performance in product-diversified firms', Academy of Management Journal, 40:767798.

Hopenhayn, H. (1992) 'Entry, Exit and Firm Dynamics in Long-Run Equilibrium', Econometrica, 60(5):1127-1150.

Huchzermeier, A. and Cohen, M.A. (1996) 'Valuing Operational Flexibility under Exchange Rate Risk'. Operations Research, 44(1): 100-113.

Inkpen, A.C. and Beamish, P.W. (1997) 'Knowledge bargaining power and the instability of joint ventures', Academy of Management Review, 22(1):177-203.

Jovanovic, B. (1982) 'Selection and the Evolution of Industry', Econometrica, 50(3): 649-670.

Killing, J.P. (1983) Strategies for Joint Venture Success, Praeger:New York.

Killing, J.P. (1982) 'How to Make A Global Joint Venture Work', Harvard Business Review, 60(3):120-127.

Kim, T.Y. and Delios, A. (2003) 'Duality of Experiential Learning and Organizational Geography: Japanese Multinational Corporations in the People's Republic of China, 1979-2001', Paper presented at the 2003 Academy of Management Meetings, Seattle.

Kim, C, W., and Hwang, P. (1992) 'Global Strategy and Multinationals' Entry Mode Choice', Journal of International Business Studies, 23(1): 29-53.

Kogut, B. (1991) 'Joint Ventures and the Option to Expand and Acquire', Management Science, 37 (1): 19-34.

Kogut, B. (1985) 'Designing global strategies: Profiting from operational flexibility'. Sloan Management Review, 26: 27-38.

Kogut, B. (1983) 'Foreign Direct Investment as a Sequential Process', In Kindelberger, Charles P. and David Audretsch, editors, The Multinational Corporations in the 1980s. Cambridge, MA: MIT Press.

Kogut, B. and Chang, S. J. (1996) 'Platform Investments and Volatile Exchange Rates: Japanese Direct Investment in US Electronic Industries', Review of Economics and Statistics, 78(2):221231.

Kogut, B. and Chang, S.J. (1991) 'Technological Capabilities and Japanese Foreign Direct Investment in the United States', Review of Economics \& Statistics, 73(3): 401-423.

Kogut, B. and Kulatilaka, N. (1994a) 'Operational Flexibility, Global Manufacturing, and the Option Value of a Multinational Network', Management Science, 40 (1): 123-139.

Kogut, B. and Kulatilaka, N. (1994b) 'Options Thinking and Platform Investment: Investing in Opportunity', California Management Review, 36(2):52-71.

Kogut, B. and Singh, H. (1988) 'The Effect of National Culture on the Choice of Entry Mode', Journal of International Business Studies, 19(3): 411-432;

Kouvelis, P., Axarloglou K. and Sinha, V. (2001) 'Exchange Rates and the Choices of Ownership Structure of Production Facilities in Supplying Foreign Markets', Management Science, 47(8):1063-1080. 
Kulatilaka, N. and Trigeorgis, L. (1994) 'The General Flexibility to Switch: Real Options Revisited', The International Journal of Finance, 6(3): 778-790.

Kumar, M.S. (1985) 'Growth, Acquisition Activity and Firm Size: Evidence from the United Kingdom', The Journal of Industrial Economics, 33(3):327-338.

Lessard, D.R. (1986) 'Finance and Global Competition: Exploiting Financial Scope and Coping with Volatile Exchange Rates'. In Michael E. Porter (eds), Copetition in Global industries. Boston, MA: Harvard Business School Press, 147-84.

Li, J. T. (1995) 'Foreign Entry and Survival: Effects of Strategic Choices on Performance in International Markets'. Strategic Management Journal 16(5): 348-362.

Li, J. and Rugman, A. (2005) 'Real Options and the Theory of Foreign Direct Investment', Working paper presented at the Annual conference of the Academy of International Business, Quebec.

Mata, J., Portugal, P. (1994) 'Life Duration of New Firms', The Journal of Industrial Economics, 42 (3): 227-245.

Mata, J. and Portugal, P. (2004) 'Patterns of Entry, Post-Entry Growth and Survival', Small Business Economics, 22(3/4):283-298.

Mata, J. and Portugal, P. (2002) 'The Survival of New Domestic and Foreign-Owned Firms'; Strategic Management Journal, 23(4): 323-343.

Mata, J. and Portugal, P. (2000) 'Closure and Divesture by Foreign Entrants: The Impact of Entry and Post-Entry Strategies', Strategic Management Journal, 21(5): 549-562.

Mansfield, E. (1962) 'Entry, Gibrat's law, Innovation and the Growth of Firms', American Economic Review, 52(5):1023-1051.

Mayer, T. and Muchielli, J.L. (1998) 'Hierarchical Location Choice and Multinational Firm Strategy', paper presented at the Western Economic Association conference at Lake Tahoe, June 28-July 2,1998.

Mello, A.S. and Parsons, J.E. (1995) 'An Integrated Model of Multinational Flexibility and Financial Hedging', Journal of International Economics, 39(1/2): 27-51.

Miller, K.D. and Reuer, (1998) 'Firm Strategy and Economic Exposure To Foreign Exchange Rate Movements', Journal of International Business Studies, 29(3): 493-513.

Orser, B.J., Hogarth-Scott, S. and Riding, A.L. (2000) 'Performance, Firm Size, and Management Problem Solving', Journal of Small Business Management, 38(4): 42-58.

Pan, Y.G. and Chi, S.K. (1999) 'Financial Performance and Survival of Multinational Corporations in China', Strategic Management Journal, 20(4): 359-374.

Pangarkar, N. and Klein, S. (2004) 'The Impact of Control on International Joint Venture Performance: Contingency Approach', Journal of International Marketing, 12(3): 86-107.

Penrose E. T. (1959) The Theory of the Growth of the Firm. London: Basil Blackwell.

Rangan, S. (1998) 'Do Multinationals Operate Flexibly? Theory and Evidence', Journal of International Business Studies, 29(2):217-237.

Reuer, J.J., Leiblein, M.J. (2000) 'Downside Risk Implications of Multinationality and International Joint Ventures', Academy of Management Journal, 43(2): 203-214.

Rosenberg, M.M., (2004) 'Firm Risk, Investment, and Employment Growth', Journal of Economics and Finance, 28(2):164-185.

Rugman, A.M. and Verbeke, A. (2001) 'Subsidiary-specific Advantages in Multinational Enterprises', Strategic Management Journal, 22(3):237-250.

Shane, S.A. (1996) 'Hybrid Organizational Arrangements and Their Implications For Firm Growth and Survival: a Study of New Franchisors', Academy of Management Journal, 39(1): 216-234.

Shaver, J. (1995) 'The Influence of Industry Growth and Foreign Entry Rate on Foreign Direct Investment Survival', Academy of Management Best Papers Proceedings: 201-205.

Shaver, J. M. and Flyer, F. (2000) 'Agglomeration Economies, Firm Heterogeneity, and Foreign Direct Investment in the United States', Strategic Management Journal, 21(12): 1175-1193. 
Shaver, J. M., Mitchell, W., and Yeung, B. (1997) 'The Effect of Own-Firm and Other-Firm Experience on Foreign Direct Investment Survival in the United States, 1987-92', Strategic Management Journal, 18(10): 811-824.

Shimizu, K. and Hitt, M.A. (2004) 'Strategic Flexibility: Organizational Preparedness to Reverse Ineffective Strategic Decisions', Academy of Management Executive, 18(4): 44-59

Song, J. Y. (2002) 'Firm Capability and Technology Ladders: Sequential Foreign Direct Investments of Japanese Electronics Firms in East Asia', Strategic Management Journal, 23 (3): 191-200.

Stopford, J.M. and Wells, L.T. Jr. (1972) Managing the Multinational Enterprise: Organization of the Firm and Ownership of the Subsidiaries. New York: Basic Books.

Sutton, J. (1997) 'Gibrat's Legacy', Journal of Economic Literature, 35(1)40-59.

Tallman, S. and Li, J.T. (1996) 'Effects of International Diversity and Product Diversity on the Performance of Multinational Firms', Academy of Management Journal, 39(1):179-196.

Tan, D. (2003) 'The Limits to the Growth of Multinational Firms in a Foreign Market', Managerial and Decision Economics, 24(8): 569-582.

Tan, D. and Mahoney, J. (2005) 'Examining the Penrose Effect in An International Business Context: the Dynamics of Japanese Firm Growth in US Industries', Managerial \& Decision Economics, 26(2): 113-127.

Tang, C.Y. and Tikoo, S. (1999) 'Operating flexibility and market valuation of earnings', Strategic Management Journal, 18 (10), 811-824.

Thompson, R.S. (1994) 'The Franchise Life Cycle and the Penrose Effect', Journal of Economic Behavior and Organization, 24(2): 207-218.

Toyo Keizai Inc, (1997) Kaigai shinshutsu kigyou souran (Directory of Japanese multinational corporations). Toyo Keizai Inc, Tokyo.

Treadway, A.B. (1970) 'Adjustment Costs and Variable Inputs in the Theory of the Competitive Firm', Journal of Economic Theory, 2(4): 329-347.

Trigeorgis, L. (1996) Real Options: Managerial Flexibility and Strategy in Resource Allocation, Cambridge, MA, MIT Press.

Vernon, R. (1979). 'The Product Cycle Hypothesis in a New International Environment', Oxford Bulletin of Economics and Statistics, 41(4):255-267.

Volberda, H. W. (1996) 'Toward the Flexible Form: How to Remain Vital in Hypercompetitve Environments', Organization Science, 7(4):7359-374.

Wheeler, D., and Mody, A. (1992) 'International Investment Location Decision', Journal of International Economics, 33(1/2):57-76.

Williams, D. (2003) 'Explaining employment changes in foreign manufacturing investment in the UK', International Business Review, 12(4):479-497.

Yamawaki, H. (1997) 'Exit of Japanese Multinationals in U.S. and European Manufacturing Industries'. In P. J. Buckley and J.-L. Mucchielli (eds.) Multinational Firms and International Relocation. Cheltenham: Edward Elgar, 234-371.

Yan, A.M. and Zeng, M. (1999) 'International Joint Venture Instability: A Critique of Previous Research, A Reconceptualization, and Directions for Future Research', Journal of International Business Studies, 30(2): 395-412.

Zaheer, S. and Mosakowki, E. (1997) 'The Dynamics of the Liability of Foreignness: A Global Study of Survival in Financial Services', Strategic Management Journal, 18(6):439-464. 


\section{Table 1}

Country distributions of Japanese electronics affiliates (divestment and employment growth, 1995-1999)

\begin{tabular}{lccccccc}
\hline & & & & & & & \\
Employment growth (95-99)
\end{tabular}


Table 2 Description and summary statistics of dependent and explanatory variables

\begin{tabular}{|c|c|c|c|c|}
\hline Name & Description & Mean & Stdev & $\begin{array}{l}\text { Hypothesis/ } \\
\text { predicted } \\
\text { sign }\end{array}$ \\
\hline affiliate growth & $\begin{array}{l}\text { average annual growth rate of affiliate's employment } \\
\text { from } 1995 \text { to early } 1999\end{array}$ & 0.06 & 0.23 & \\
\hline labor cost growth & $\begin{array}{l}\text { annual increase in the yearly dollar wage in the } \\
\text { country's electronics industry during the period of } \\
\text { 1995-1998 }\end{array}$ & -0.26 & 2.28 & H1: - \\
\hline $\begin{array}{l}\text { joint venture*labor cost } \\
\text { growth }\end{array}$ & $\begin{array}{l}\text { interaction of joint venture dummy with labor cost } \\
\text { growth }\end{array}$ & -0.46 & 1.63 & $\mathrm{H} 2:+$ \\
\hline demand growth & $\begin{array}{l}\text { the percentage growth in the dollar value of the } \\
\text { country's electronics market demand between } 1995 \text { to } \\
1998\end{array}$ & 0.08 & 0.37 & H1: + \\
\hline joint venture*demand growth & $\begin{array}{l}\text { interaction of joint venture dummy with market } \\
\text { growth }\end{array}$ & 0.07 & 0.31 & H2: - \\
\hline network labor cost growth & $\begin{array}{l}\text { average of labor cost growth in those Asian countries } \\
\text { in which parent firm had manufacturing operations in } \\
\text { 1995, except for the focal country. }\end{array}$ & -0.45 & 3.14 & H3: + \\
\hline $\begin{array}{l}\text { joint venture * network labor } \\
\text { cost growth }\end{array}$ & $\begin{array}{l}\text { interaction of joint venture dummy with network } \\
\text { labor cost growth }\end{array}$ & -0.20 & 2.26 & H4: - \\
\hline $\begin{array}{l}\text { share of joint ventures in } \\
\text { network * network labor cost } \\
\text { growth }\end{array}$ & $\begin{array}{l}\text { interaction share of joint ventures in network (the } \\
\text { ratio of the number of joint ventures to the total } \\
\text { number of affiliates in the network, except for the } \\
\text { focal country) with network labor cost growth }\end{array}$ & -0.32 & 1.70 & H5: - \\
\hline parent size & $\begin{array}{l}\text { the logarithm of parent firm sales (million Yen) in } \\
1995\end{array}$ & 11.08 & 2.36 & \\
\hline parent patent intensity & $\begin{array}{l}\text { the number of US patents granted to the parent firm } \\
\text { during 1993-1999 times } 1000 \text {, divided by parent sales } \\
\text { in } 1995\end{array}$ & 0.85 & 1.49 & \\
\hline $\begin{array}{l}\text { parent prior country } \\
\text { experience }\end{array}$ & $\begin{array}{l}\text { the number of manufacturing affiliates established by } \\
\text { the parent firm in the country prior to the entry of the } \\
\text { focal affiliate. }\end{array}$ & 0.82 & 1.80 & \\
\hline affiliate size & $\begin{array}{l}\text { the logarithm of the number of employees of the } \\
\text { affiliate in } 1995\end{array}$ & 5.64 & 1.40 & \\
\hline affiliate age & $\begin{array}{l}\text { the number of years the affiliate had been in operation } \\
\text { until } 1995\end{array}$ & 8.91 & 8.02 & \\
\hline affiliate age square & square of affiliate age & 143.63 & 218.22 & \\
\hline joint venture & $\begin{array}{l}\text { dummy taking value } 1 \text { if the parent firm holds less } \\
\text { than a } 95 \% \text { stake in the affiliate }\end{array}$ & 0.53 & 0.50 & \\
\hline acquired affiliate & $\begin{array}{l}\text { dummy taking the value } 1 \text { if the affiliate was acquired } \\
\text { by the Japanese parent }\end{array}$ & 0.00 & 0.07 & \\
\hline expatriate intensity & $\begin{array}{l}\text { number of Japanese expatriates divided by the total } \\
\text { number of employees in } 1995\end{array}$ & 0.02 & 0.04 & \\
\hline fdi inflow & $\begin{array}{l}\text { the average dollar value of annual inward direct } \\
\text { investment flows to the country between } 1995 \text { to } 1998 \\
\text { in billion dollars }\end{array}$ & 13.34 & 15.79 & \\
\hline
\end{tabular}


Table 3 Estimation results of employment growth of Japanese electronics affiliates (1995-1999)

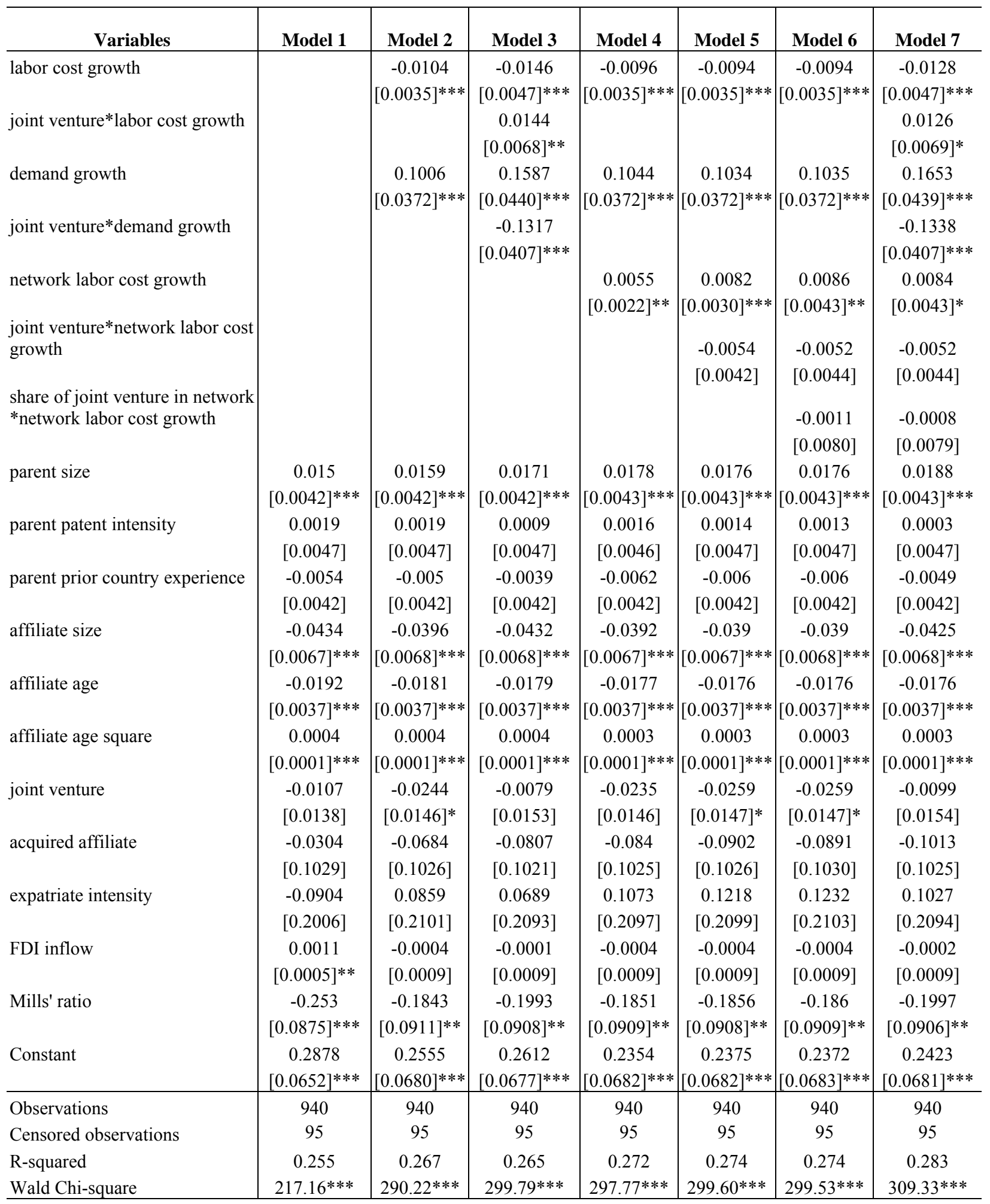

Standard errors in brackets; $*$ significant at $10 \% ; * *$ significant at $5 \% ; * * *$ significant at $1 \%$ 


\section{Appendix I: Probit model of survival of Japanese electronics affiliates}

\section{Model specification}

The survival equation follows a basic specification in Belderbos and Zou (2005). It includes the dummy variable country platform affiliate, taking the value 1 if an affiliate is the only manufacturing affiliate of its parent in the country in 1995. It is expected to have a positive sign if MNEs value the flexibility option of maintaining at least one manufacturing plant in a country. We also include a set of variables similar to the control variables in the growth equation: parent size, parent patent intensity and parent prior country experience at the parent level; at the affiliate level affiliate size, affiliate age and affiliate age squared, three entry mode dummies (majority owned joint venture in case of 51-95 percent equity stake, minority owned joint venture in case of equity stake smaller than 50 percent, and acquired affiliate), and the expatriate intensity of the affiliate (the number of Japanese expatriates divided by the total number of employees in 1995); at the country level, labor cost growth, demand growth, and FDI inflow.

\section{Estimation results}

Results from the survival equation are largely consistent with our expectation and earlier studies on affiliate survival (Table A1). The model is highly significant as indicated by the Chi-square test statistic. The country platform affiliate dummy has the expected positive sign and is highly significant. Parent size is positive and highly significant. Both Parent patent intensity and parent prior country experience have the expected positive sign but are insignificant. Among affiliate level variables, affiliate size is positive and significant. Affiliate age is negatively signed and significant while the squared term is positive but not significant, suggesting that older affiliates may still rely on mature technologies or focus on markets with less growth potential (e.g. Hannan, 1998; Li, 1995). Minority owned joint ventures, are significantly (at the 10 percent level) less likely to survive than wholly owned affiliates, but a similar impact is not found for majority owned joint ventures or acquisitions. The expatriate intensity is positive and significant. Among the country variables, labor cost growth is negative and significant at 10\% level. Demand growth and FDI inflow are insignificant. 
Table A1. Estimation results for the survival equation (Equation 1)

\begin{tabular}{|c|c|}
\hline & Model \\
\hline Country platform affiliate & $\begin{array}{c}0.4655 \\
{[0.1383]^{\star \star *}}\end{array}$ \\
\hline parent size & $\begin{array}{c}0.1196 \\
{[0.0344]^{\star * *}}\end{array}$ \\
\hline parent patent intensity & $\begin{array}{c}0.0451 \\
{[0.0564]}\end{array}$ \\
\hline parent prior country experience & $\begin{array}{c}0.02 \\
{[0.0542]}\end{array}$ \\
\hline affiliate size & $\begin{array}{c}0.1479 \\
{[0.0533]^{\star * *}}\end{array}$ \\
\hline affiliate age & $\begin{array}{c}-0.0609 \\
{[0.0304]^{\star *}}\end{array}$ \\
\hline affiliate age square & $\begin{array}{c}0.0016 \\
{[0.0011]}\end{array}$ \\
\hline majority owned joint venture & $\begin{array}{c}0.1971 \\
{[0.1655]}\end{array}$ \\
\hline minority owned joint venture & $\begin{array}{c}-0.2435 \\
{[0.1423]^{*}}\end{array}$ \\
\hline acquired affilaite & $\begin{array}{c}-0.6522 \\
{[0.6622]}\end{array}$ \\
\hline expatriate intensity & $\begin{array}{c}5.5377 \\
{[2.6602]^{* *}}\end{array}$ \\
\hline labor cost growth & $\begin{array}{c}-0.0498 \\
{[0.0269]^{*}}\end{array}$ \\
\hline market growth & $\begin{array}{c}-0.0584 \\
{[0.3077]}\end{array}$ \\
\hline FDI inflows & $\begin{array}{c}0.0042 \\
{[0.0076]}\end{array}$ \\
\hline Constant & $\begin{array}{c}-0.8489 \\
{[0.4463]^{*}}\end{array}$ \\
\hline Observations & 1035 \\
\hline Pseudo R-square & 0.112 \\
\hline LR Chi-square & $71.22^{\star * *}$ \\
\hline Log Likelihood & -281.78 \\
\hline
\end{tabular}


Appendix II Correlation matrix of explanatory variables

\begin{tabular}{|c|c|c|c|c|c|c|c|c|c|c|c|c|c|c|c|c|c|c|c|}
\hline & Variables & 1 & 2 & 3 & 4 & 5 & 6 & 7 & 8 & 9 & 10 & 11 & 12 & 13 & 14 & 15 & 16 & 17 & 18 \\
\hline 1 & Affiliate growth & 1.00 & & & & & & & & & & & & & & & & & \\
\hline 2 & labor cost growth & -0.05 & 1.00 & & & & & & & & & & & & & & & & \\
\hline 3 & joint venture*labor cost growth & 0.04 & 0.74 & 1.00 & & & & & & & & & & & & & & & \\
\hline 4 & demand growth & 0.27 & 0.25 & 0.35 & 1.00 & & & & & & & & & & & & & & \\
\hline 5 & joint venture*demand growth & 0.20 & 0.27 & 0.40 & 0.82 & 1.00 & & & & & & & & & & & & & \\
\hline 6 & network labor cost growth & 0.06 & -0.12 & -0.05 & -0.03 & -0.03 & 1.00 & & & & & & & & & & & & \\
\hline 7 & $\begin{array}{l}\text { joint venture*network labor cost } \\
\text { growth }\end{array}$ & 0.00 & -0.02 & -0.04 & -0.05 & -0.07 & 0.71 & 1.00 & & & & & & & & & & & \\
\hline 8 & $\begin{array}{l}\text { share of joint venture in network } \\
{ }^{*} \text { network labor cost growth }\end{array}$ & 0.03 & -0.09 & -0.04 & -0.05 & -0.04 & 0.86 & 0.71 & 1.00 & & & & & & & & & & \\
\hline 9 & parent size & 0.08 & -0.03 & -0.02 & 0.05 & 0.09 & -0.22 & -0.19 & -0.19 & 1.00 & & & & & & & & & \\
\hline 10 & parent patent intensity & 0.05 & 0.01 & -0.01 & 0.05 & 0.00 & -0.08 & -0.09 & -0.11 & 0.36 & 1.00 & & & & & & & & \\
\hline 11 & parent prior country experience & 0.12 & 0.05 & 0.06 & 0.16 & 0.20 & 0.00 & -0.01 & 0.02 & 0.42 & 0.08 & 1.00 & & & & & & & \\
\hline 12 & affiliate size & -0.25 & 0.02 & 0.06 & -0.09 & -0.12 & -0.10 & -0.06 & -0.06 & 0.41 & 0.17 & 0.06 & 1.00 & & & & & & \\
\hline 13 & affiliate age & -0.39 & -0.09 & -0.16 & -0.32 & -0.30 & -0.03 & -0.02 & -0.03 & 0.13 & 0.06 & -0.21 & 0.27 & 1.00 & & & & & \\
\hline 14 & affiliate age square & -0.32 & -0.10 & -0.15 & -0.22 & -0.20 & -0.02 & -0.01 & -0.02 & 0.15 & 0.06 & -0.17 & 0.24 & 0.96 & 1.00 & & & & \\
\hline 15 & joint venture & 0.04 & -0.28 & -0.27 & 0.11 & 0.20 & 0.03 & -0.08 & 0.00 & -0.02 & -0.08 & 0.06 & -0.14 & -0.02 & 0.03 & 1.00 & & & \\
\hline 16 & acquired affiliate & -0.03 & 0.01 & 0.02 & 0.01 & -0.01 & 0.03 & 0.01 & 0.05 & 0.03 & 0.02 & -0.01 & 0.02 & 0.04 & 0.03 & -0.07 & 1.00 & & \\
\hline 17 & expatriate intensity & 0.14 & 0.20 & 0.09 & 0.05 & 0.05 & -0.04 & 0.03 & 0.00 & -0.11 & -0.09 & -0.03 & -0.41 & -0.10 & -0.07 & -0.08 & 0.00 & 1.00 & \\
\hline 18 & FDI inflow & 0.28 & 0.26 & 0.29 & 0.87 & 0.73 & -0.02 & -0.03 & -0.05 & 0.03 & 0.02 & 0.20 & -0.12 & -0.42 & -0.32 & 0.14 & 0.00 & 0.05 & 1.00 \\
\hline
\end{tabular}

Note: Significance level is indicated in bold ( 5 percent) or in italics (10 percent). 